\title{
The effect of self-esteem, attitude towards the body, and eating habit on cognitive reactivity
}

\author{
Dian Veronika Sakti Kaloeti, ${ }^{1 *}$ Lusi Nur Ardhiani ${ }^{1}$ \\ ${ }^{1}$ Faculty of Psychology, Universitas Diponegoro, Semarang - Indonesia
}

\begin{abstract}
An increase in the prevalence of unhealthy lifestyles, including dietary problems, is being experienced by students, especially women. This study aims to examine the model of whether self-esteem, attitude towards the body, eating habits, and Body Mass Index (BMI) affects cognitive reactivity in female students. The nonprobability convenience sampling technique was employed. A total of 140 female students in Semarang, Indonesia, aged 18-22 participated in this study. The measuring instruments used were the Rosenberg Self-Esteem Scale (RSES), the Dresden Body Image Questionnaire (DBIQ), and the Adult Eating Habit Questionnaire (AEHQ). Analysis was made using partial least squares structural equation modeling (PLS-SEM). The results show that self-esteem significantly and positively affected attitudes towards the body $\left(\mathrm{R}^{2}=36.3 \%, \mathrm{p}<.01\right)$, and significantly and negatively affected BMI $\left(\mathrm{R}^{2}=1.7 \%, \mathrm{p}<.05\right)$ and cognitive reactivity $\left(\mathrm{R}^{2}=35.8 \%, \mathrm{p}<.01\right)$. Furthermore, attitudes towards the body significantly mediated the relationship between self-esteem and eating habits $(\beta=0.166, p<.01)$, and also significantly mediated the relationship between self-esteem and BMI $(\beta=-0.157, p<.01)$. Based on the results, the development of psychological interventions regarding self-esteem as health promotion in relation to lifestyle is highly recommended.
\end{abstract}

Keywords: Body Mass Index; BMI; cognitive reactivity; female university student; psychological factors; self-esteem

Abstrak: Kenaikan prevalensi gaya hidup yang tidak sehat, termasuk masalah diet dialami oleh mahasiswa khususnya perempuan. Penelitian ini bertujuan untuk menguji model apakah harga diri, sikap terhadap tubuh, kebiasaan makan, dan Indeks Massa Tubuh (IMT) mempengaruhi reaktivitas kognitif pada mahasiswi. Pengambilan sampel menggunakan teknik non probability convenience sampling. Sebanyak 140 mahasiswi di Semarang, berusia 18-22 tahun berpartisipasi dalam penelitian ini. Alat ukur yang digunakan adalah The Rosenberg Self-Esteem Scale (RSES), The Dresden Body Image Questionnaire (DBIQ), dan Adult Eating Habit Questionnaire (AEHQ). Analisis menggunakan Partial LeastSquare Structural Equation Modeling (PLS-SEM). Hasil penelitian menunjukkan, harga diri signifikan positif mempengaruhi sikap terhadap tubuh $\left(\mathrm{R}^{2}=36,3 \%, \mathrm{p}<0,01\right)$, signifikan negatif mempengaruhi IMT $\left(\mathrm{R}^{2}=1,7 \%, \mathrm{p}<0,05\right)$ dan reaktivitas kognitif $\left(\mathrm{R}^{2}=35,8 \%\right.$, $\mathrm{p}<0,01)$. Selanjutnya, sikap terhadap tubuh signifikan memediasi hubungan antara harga diri dengan kebiasaan makan $(\beta=0,166, p<0,01)$, juga signifikan sebagai mediasi hubungan antara harga diri dengan IMT $(\beta=-0,157, p<0,01)$. Berdasarkan hasil ini maka perlu dikembangkan intervensi psikologis mengenai self-esteem sebagai promosi kesehatan dalam kaitannya dengan gaya hidup.

Kata Kunci: faktor psikologis; harga diri; Indeks Massa Tubuh; IMT; mahasiswi; reaktivitas kognitif

\footnotetext{
*Corresponding Author: Dian Veronika Sakti Kaloeti (dvs.kaloeti@live.undip.ac.id), Faculty of Psychology, Universitas Diponegoro, Jl. Prof. Soedarto, SH, Kampus Undip Tembalang, Semarang 50275-Indonesia.
} 


\section{Introduction}

The life of a college student requires adaptive skills since several substantial life-changing transitions occur when a young adult starts attending university (Sogari et al., 2018). The transition period from adolescence into young adulthood which includes transition in social relations, financial obligations, and expectations of academic achievement are phases entered by college students (Blair, 2016). The complexity of the situation could trigger psychological distress. Cognitive reactivity is psychological vulnerability marked by cognitive dysfunction and negative behavioral patterns in responding to suppressing situations (Scher et al., 2005). Inability to respond to challenges experienced by college student affect their cognitive reactivity. Van der Does (2002) identifies six main dimensions of cognitive reactivity which include helpless feeling, acceptance, aggression, control, avoiding risks, and contemplation. Further, it was found that cognitive reactivity significantly contributed to depression (Minkwitz et al., 2019).

Research showed that in a negative emotional situation, women tend to eat more than than they do in positive emotional situations (Debeuf et al., 2018). A previous study also revealed that female college students often avoid certain kinds of food due to their concerns about weight (Deshpande et al., 2009). Excessive cognitive reactivity could also contribute to excessive eating habits (Kakoschke et al., 2019). An individual will eat more when their cognitive process is vulnerable (Kakoschke et al., 2019; Tapera et al., 2017). Research by Hye Kyung and Jin Hee revealed that eating habit becomes one of the factors which contribute to developing obesity (Hye Kyung \& Jin Hee, 2009). Unhealthy eating habits such as irregular meal time, consuming junk food and high-calory snacks, and minimum consumption of fruits and vegetables were also identified when an individual enters university (Gerend, 2009; Sogari et al,, 2018). Other factors which influenced eating habit and attitude were time restriction, comfortableness, cost, and food taste (Hebden et al., 2015).

College students are one of the groups with a higher risk of obesity. Less physical activity, a lot of stress, and unhealthy eating habits make this group more vulnerable (Ramalho et al., 2012). According to several credible sources, college life is a critical period for young adults in terms of their food choices and weight gain. Some studies have shown that college students tend to gain more weight than those who do not attend University (Racette et al,, 2008; Sogari et al., 2018; Vella-Zarb \& Elgar, 2009). Another study also stated that age and educational degrees influence weight because they relate to the change in the daily activities of college students (Tapera etal., 2017).

Eating habits and attitudes during college life may exert a big impact on lifestyle during adulthood (Sogari et al,, 2018). Unhealthy eating habits and attitudes could also trigger health issues including obesity. Obesity and overweight are conditions when abnormal or excessive fat accumulation occurs and may impair physical functions or increase health risks (Purnell, 2018). According to the Ministry of Health's Basic Health Research data, Central Java was one of the provinces with a higher prevalence of obesity in comparison with the national prevalence. In 2013, the prevalence of obesity in females was $32.9 \%$ while males were 19.7\% (Balitbangkes, 2013). Certain standards must be set to assess obesity condition, and. one of them is the Body Mass Index (BMI). BMI is the number obtained as the result of dividing the mass of the body in the unit of kilogram with height in the unit of meter. An individual with higher than or 
equal to 30 may be classified as obese (Alasmari et al., 2017). The case of obesity generally occurs mostly in females since their physical conditions are biologically more adaptive to store more fat (Davis et al., 2009). A study also found that dietary behavior, poor mental health, and physical or sexual childhood abuse were associated with overweight and obesity in women (Peltzer etal., 2014).

Body attitude is related to weight in women, which is stated that attitude toward the body is a reaction or judgment of self-physical appearance (Heider et al., 2015). It relates to the physical condition of certain parts of the body (Montgomery Sklar, 2017). Also, it was found that females have more negative perceptions than males including dissatisfaction about certain parts of the body (Kurniawan et al., 2015). While other studies stated that dissatisfied attitude towards the body is identified more in obese adolescents than adolescents with normal weight (Uçar et al., 2010). Body attitude relates to the dimensions of cognitive reactivity especially acceptance (Da Rocha Morgado, Campana, Da Consolação, \& Tavares, 2014).

Furthermore, body attitude and obesity in adolescents related to their self-esteem (Da Rocha Morgado et al., 2014; Harriger \& Thompson, 2012). Rosenberg stated that self-esteem is an individual's positive or negative attitude about themself (Stets \& Burke, 2014). Likewise, AbdelKhalek (2016) defines self-esteem as a descriptive concept created by an individual about him or herself. This concept is influenced by an individual's social interactions. Perrin, Boone-Heinonen, Field, Coyne-Beasley, and Gordon-Larsen (2009) explain that there is a connection between obesity and self-esteem in the adolescent that is caused by several things such as peer bullying, parental criticisms about body weight and beliefs among adolescents that they are unable to control their weights. Based on the explanations above, this research aimed to test the model whether selfesteem, attitude towards body, eating habits, and Body Mass Index (BMI) affect cognitive reactivity in female college students. Further, the hypotheses that will be developed in this study are as follows: H1.a = self-esteem has a positive and significant effect on body attitude and eating habits. H1.b = self-esteem has a negative and significant effect on BMI and cognitive reactivity. $\mathrm{H} 2 . \mathrm{a}=$ body attitude has a positive and significant effect on eating habits. H2.b = body attitude has a negative and significant effect on BMI and cognitive reactivity. H3.a = eating habit has a negative and significant effect on BMI. H3.b = eating habit has a positive and significant effect on cognitive reactivity. $\mathrm{H} 4=$ BMI has a positive and significant effect on cognitive reactivity. H5.a = Body attitude mediates the relationship between self-esteem and eating habits. H5.b = Body attitude mediates the relationship between self-esteem and BMI. H6 = Eating habit mediates the relationship between body attitude and BMI. H7.a = BMI mediates the relationship between self-esteem and cognitive reactivity. H7.b = BMI mediates body attitude towards cognitive reactivity. H7.c $=$ BMI mediates eating habits against cognitive reactivity.

\section{Method}

Participants in this research were female college students aged 18-22 years. The sampling method used non-probability sampling with a convenience sampling technique. Before data collection, we notified the research participants about the purpose of the study.

The research participants attended the data collection on the agreed day that they deemed most convenient, between 17 and 27 June 2019. Explanations about the purpose of the study were 
given to all participants and those who agreed to participate signed the informed consent forms before we started the data collection. The participants filled in the questionnaires in a classroom. Permission for research projects and data collection were obtained from the Faculty of Psychology, Universitas Diponegoro, Semarang, Indonesia.

The instruments used in this study were adapted and translated using guidelines from Beaton, Bombardier, Guillemin, \& Ferraz (2000). In the measurement translation, two clinical psychologists performed forward translation. Next, the Bahasa Indonesia version was backtranslated by a language expert who had not seen the original English version. At this phase, we managed to reach a consensus about grammar, conceptual equivalence, and semantics. The prefinal version of Bahasa Indonesia measures was reviewed and approved by a panel of clinical psychologists and language experts. This version was tested to 5 female college students. They were asked if any terms and sentences were unclear or difficult to understand. The results show that the instruments were very easy to fill out and easily understood by the participants. Thus, the reliability and validity of the final instruments were tested.

The Rosenberg Self-Esteem Scale (RSES), is a scale that globally measures self-esteem through positive and negative feelings about oneself, which contains 10 items. RSES is unidimensional. A higher total score portrays more positive selfdignity. Coefficient Cronbach's alpha RSES obtained for this research is 0.875 .

The Dresden Body Image Questionnaire (DBIQ) consists of 35 items related to individual attitudes towards the shape of the body (Pöhlmann et al., 2013). DBIQ consists of five scale subs: acceptance of body, vitality, physical contact, fulfilling sexual needs, and self-aggrandizement. A higher total score portrays an individual's more positive attitude towards the shape of the body. Coefficient Cronbach's alpha DBIQ obtained for this research is 840 .

Adult Eating Habit Questionnaire (AEHQ), measures eating habits or behavior of an individual which consists of 35 items and is divided into food responsiveness, emotional over-eating, enjoyment of food, satiety responsiveness, emotional under-eating, and slowness in eating (Hunot et al., 2016). Coefficient Cronbach's alpha AEHQ obtained for this research is 863 .

Analysis using Partial Least Square Structural Equation Modeling (PLS-SEM) approach using WarpPLS 5 program. Data analysis techniques were carried out in two ways: descriptive analysis and statistical analysis. In a descriptive analysis, different tests were performed to see whether there were differences among variables. Statistical analysis was carried out in several stages, namely: 1) Testing the validity and reliability based on the factor loading value. Indicators are considered valid if they have a factor loading value .5 so it could be concluded that the measurement met the convergent validity criteria (Chin, 1998); 2) Hypothesis testing.

\section{Results}

\section{Validity and reliability}

This study used a convergent validity test to ensure that the indicator used is indeed a construct of the latent variable. Convergent validity can be seen from the correlation between the indicator score and the variable score. The variable of selfesteem has 1 indicator, body image has 14 indicators, eating habit has 12 indicators, and 
cognitive reactivity has 10 indicators, and all these indicators have a factor value of less than .5 . Therefore, these indicators will not be used in the model. The validity test results are presented in Table 1.

Table 2 shows that the AVE values on all variables are $>.5$. A construct validity test was used to ensure that the indicator was indeed extracted from its latent variable. Thus, it could be concluded that all indicators used in this study have met discriminant validity.

Reliability testing used composite reliability, where the value must be $>.7$ (Chin, 1998). Table 2 shows that the composite reliability value on the variables of self-esteem, body image, eating habits, $\mathrm{BMI}$, and cognitive reactivity are all $>$.7. This shows that the variables are consistent and can be used further for hypothesis testing.

Table 1

Validity Analysis

\begin{tabular}{|c|c|c|c|c|c|c|c|}
\hline Variable & Indicator & $\begin{array}{l}\text { Outer } \\
\text { Loading }\end{array}$ & $(>.5)$ & Variable & Indicator & $\begin{array}{l}\text { Outer } \\
\text { Loading }\end{array}$ & $(>.5)$ \\
\hline \multirow[t]{9}{*}{ Self-esteem } & SE1 & .706 & valid & \multirow[t]{21}{*}{ Eating habit } & EH1 & .561 & valid \\
\hline & SE2 & .714 & valid & & EH3 & .884 & valid \\
\hline & SE3 & .702 & valid & & $\mathrm{EH} 4$ & .595 & valid \\
\hline & SE4 & .668 & valid & & EH5 & .563 & valid \\
\hline & SE5 & .781 & valid & & EH6 & .605 & valid \\
\hline & SE6 & .674 & valid & & EH8 & .795 & valid \\
\hline & SE7 & .788 & valid & & EH9 & .511 & valid \\
\hline & SE9 & .774 & valid & & EH10 & .620 & valid \\
\hline & SE10 & .546 & valid & & EH12 & .848 & valid \\
\hline \multirow[t]{22}{*}{ Body attitude } & DB1 & .649 & valid & & EH13 & .615 & valid \\
\hline & DB3 & .538 & valid & & EH14 & .646 & valid \\
\hline & DB5 & .509 & valid & & EH16 & .544 & valid \\
\hline & DB7 & .654 & valid & & EH17 & .599 & valid \\
\hline & DB8 & .543 & valid & & EH19 & .639 & valid \\
\hline & DB9 & .639 & valid & & EH21 & .522 & valid \\
\hline & DB10 & .623 & valid & & EH22 & .560 & valid \\
\hline & DB12 & .719 & valid & & $\mathrm{EH} 24$ & .554 & valid \\
\hline & DB13 & .392 & valid & & EH26 & .467 & valid \\
\hline & DB14 & .558 & valid & & EH28 & .509 & valid \\
\hline & DB16 & .843 & valid & & EH32 & .637 & valid \\
\hline & DB17 & .748 & valid & & EH33 & .538 & valid \\
\hline & DB18 & .642 & valid & \multirow{10}{*}{$\begin{array}{l}\text { BMI } \\
\text { Cognitive reactivity }\end{array}$} & BMI & 1 & valid \\
\hline & DB20 & .542 & valid & & LR3 & .655 & valid \\
\hline & DB21 & .601 & valid & & LR5 & .675 & valid \\
\hline & DB25 & .707 & valid & & LR7 & .508 & valid \\
\hline & DB29 & .768 & valid & & LR9 & .662 & valid \\
\hline & DB31 & .649 & valid & & LR11 & .735 & valid \\
\hline & DB32 & .604 & valid & & LR12 & .531 & valid \\
\hline & DB34 & .585 & valid & & LR13 & .611 & valid \\
\hline & DB35 & .621 & valid & & LR16 & .837 & valid \\
\hline & & & & & LR17 & .718 & valid \\
\hline
\end{tabular}

Source: Primary data, 2020

Table 2

Value of Average Variance Extracted (AVE)

\begin{tabular}{lrr}
\hline Variable & Average Variance Extracted & \\
\hline Self-esteem & .504 & Valid
\end{tabular}


D. V. S. Kaloeti, L. N. Ardhiani

\begin{tabular}{lrl}
\hline & & \\
Body attitude & .524 & Valid \\
Eating habit & .732 & Valid \\
BMI & 1 & Valid \\
Cognitive reactivity & .892 & Valid \\
\hline
\end{tabular}

Source: Primary data, 2020

Table 3

Reliability Testing

\begin{tabular}{lrrr}
\hline Variable & Cronbach's Alpha & Composite Reliability & (Cut off >.7) \\
\hline Self-esteem & .875 & .9 & Reliable \\
Body attitude & .84 & .867 & Reliable \\
Eating habit & .863 & .885 & Reliable \\
BMI & 1 & 1 & Reliable \\
Cognitive reactivity & .881 & .899 & Reliable \\
\hline
\end{tabular}

Source: Primary data, 2020

Table 4

G-Power Results

\begin{tabular}{lrrr}
\hline Variable & $\begin{array}{r}\text { Number of } \\
\text { Independent } \\
\text { Variable }\end{array}$ & Size of Sample & $\begin{array}{r}\text { Statistical Power } \\
\text { (Cut off value }>.8 \text { ) }\end{array}$ \\
\hline Self-esteem & 1 & 140 & 1 \\
Body attitude & 2 & 140 & .84 \\
Eating habit & 3 & 140 & .99 \\
BMI & 4 & 140 & 1 \\
\hline
\end{tabular}

Source: Primary data, 2020

Table 5

$R$ Square Value

\begin{tabular}{lll}
\hline Variable & $\mathrm{R}^{2}$ & \\
\hline Body attitude & .363 & Moderate \\
Eating habit & .071 & Weak \\
BMI & .17 & Weak \\
Cognitive reactivity & .358 & Moderate \\
\hline
\end{tabular}

Source: Primary data, 2020

Hypothesis testing

A statistical power analysis was performed for sample size estimation. With power value $>.8$, as is shown in Table 4, the size of the sample is adequate for the main objective of this study and can confidently read the estimated results in the model. Structure Model testing through the coefficients of determination value $\left(\mathrm{R}^{2}\right)$ and path 
coefficients results are presented in Table 5 to Table 7.

The coefficients of determination value $\left(\mathrm{R}^{2}\right)$ can be categorized as strong if the $R^{2}$ value $\geq .67$, moderate $\geq .33$, and weak $\geq .19$ (Hair et al., 2011). Table 5 shows that self-esteem has a moderate predictive ability of body attitude of $36.3 \%$ and cognitive reactivity of $35.8 \%$. Furthermore, selfesteem has a weak predictive ability for eating habits of $0.7 \%$ and BMI of $1.7 \%$.

Structural model testing aimed to determine whether there is influence between variables in the model. The T-statistic value would be compared with the T-table which is> 1.96 at a significance level of $5 \%$. The results in the original sample indicate the direction of a positive or negative relationship, while the T-statistic shows the significance of the relationship.

Table 6 shows that self-esteem has a significant effect on body attitude with a statistical Tstatistic of 8.149 and not a significant effect on eating habits. Hypotheses 1.a is partially accepted. Self-esteem has a negative significant effect on BMI with a statistical T-statistic of -2.062 and Cognitive reactivity with a T-statistic of -7.267 Hypotheses 1.b are accepted. Next, body attitude has a significant positive effect on eating habits with $\mathrm{T}$ statistic 3.481. Hypothesis 2.a is accepted. Body

Figure 1

Modeling Hypothesis Results

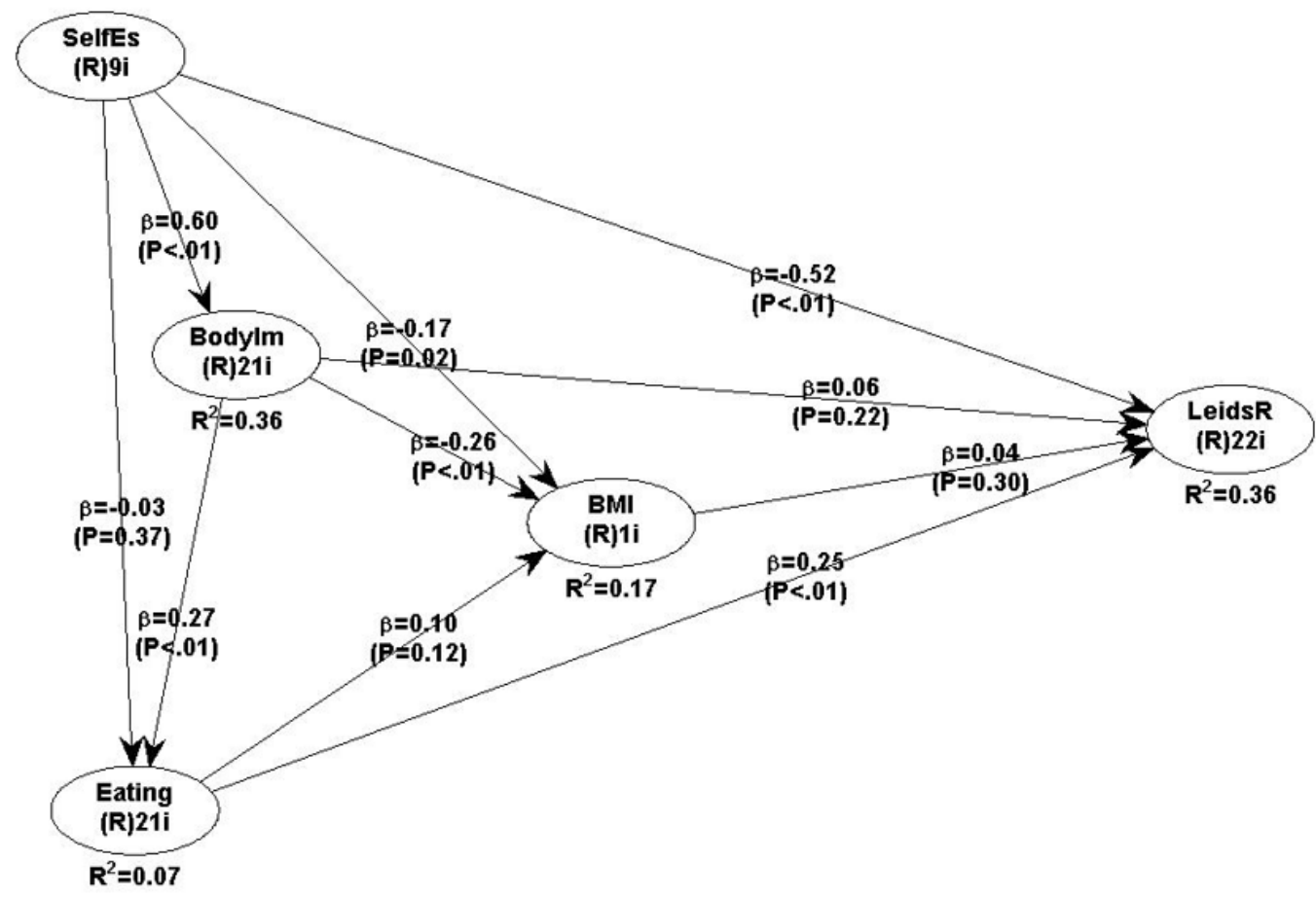

attitude has a significant negative effect on BMI with a T-statistic of -3.250, but not significant on cognitive reactivity. Hypothesis 2.b is partially accepted. The eating habit has no significant effect on BMI. Hypothesis 3 is rejected. The eating habit has a significant positive effect on cognitive 
reactivity with T-statistics 3.175 . Hypothesis $3 . \mathrm{b}$ is accepted. BMI has a significant effect on cognitive reactivity. Hypothesis 4 is rejected.

From Table 7, it can be seen that body attitude significantly mediates the relationship between self-esteem and eating habits. This can be seen from the T-statistic value of 2.862 which is greater than 1.96. Hypothesis 5.a is accepted. The mediation of body image variables is full mediation because the beta produced by testing the indirect effect is greater and more significant than the beta value of the direct relationship. Beta values can be seen through the original sample, where the indirect effect has a beta value of 0.166 while the direct effect has a beta value of -0.027 . Furthermore, body attitude significantly mediated the relationship of self-esteem with BMI, seen from the T-statistic value of -2.707. Hypothesis 5.b is accepted. Body image variable mediation is partial mediation because the beta produced by testing the indirect effect is smaller than the beta value of the direct relationship. Beta values can be seen through the original sample, where the indirect effect has a beta value of -0.157 while the direct effect has a beta value of -0.167 . Next, eating habits does not significantly mediate the relationship between body image with BMI. Hypothesis 6 is rejected. Furthermore, BMI does not significantly mediate the relationship of self-esteem with cognitive reactivity, body image with cognitive reactivity, and eating habits with cognitive reactivity. Hypothesis 7 is rejected.

Table 6

Direct Effect Results

\begin{tabular}{|c|c|c|c|c|c|c|c|c|}
\hline & $\begin{array}{l}\text { Original } \\
\text { Sample }\end{array}$ & $\beta$ & SE & $\mathrm{f}^{2}$ & $\begin{array}{c}\mathrm{T}- \\
\text { statistic }\end{array}$ & $\begin{array}{c}p- \\
\text { value }\end{array}$ & & \\
\hline Self-esteem $\rightarrow$ Body attitude & 0.603 & 0.603 & 0.074 & 0.363 & 8.149 & .001 & Significant & \\
\hline Self-esteem $\rightarrow$ BMI & -0.167 & -0.027 & 0.084 & 0.002 & -2.062 & .021 & Significant & \\
\hline Self-esteem $\rightarrow$ Eating habit & -0.027 & -0.167 & 0.081 & 0.055 & -0.321 & .374 & Not significan & \\
\hline $\begin{array}{l}\text { Self-esteem } \rightarrow \text { Cognitive } \\
\text { reactivity }\end{array}$ & -0.519 & -0.519 & 0.075 & 0.296 & -7.267 & .001 & Significant & \\
\hline Body attitude $\rightarrow$ Eating habit & 0.268 & 0.268 & 0.079 & 0.074 & 3.292 & .001 & Significant & \\
\hline Body attitude $\rightarrow$ BMI & -0.260 & -0.260 & 0.080 & 0.097 & -3.250 & .001 & Significant & \\
\hline $\begin{array}{l}\text { Body attitude } \rightarrow \text { Cognitive } \\
\text { reactivity }\end{array}$ & 0.063 & 0.063 & 0.083 & 0.019 & 0.759 & .224 & Not significan & \\
\hline Eating habit $\rightarrow$ BMI & 0.096 & 0.096 & 0.083 & 0.018 & 1.157 & .123 & Not significan & \\
\hline $\begin{array}{l}\text { Eating habit } \rightarrow \text { Cognitive } \\
\text { reactivity }\end{array}$ & 0.254 & 0.254 & 0.080 & 0.072 & 3.175 & .001 & Significant & Accepted \\
\hline BMI $\rightarrow$ Cognitive reactivity & 0.054 & 0.044 & 0.084 & 0.01 & 0.651 & .651 & $\begin{array}{l}\text { Not } \\
\text { significant }\end{array}$ & Rejected \\
\hline
\end{tabular}

Source: Primary data, 2020

Table 7

Indirect Effect Results

Original T- p-value Accepted/


The effect of self-esteem, attitude towards the body, and eating habit ....

\begin{tabular}{lcccll}
\hline & Sample & statistic & & & Rejected \\
\hline Self-esteem $\rightarrow$ Body attitude $\rightarrow$ Eating & 0.166 & 2.862 & .002 & Significant & Accepted \\
habit & -0.157 & -2.707 & .004 & Significant & Accepted \\
Self-esteem $\rightarrow$ Body attitude $\rightarrow$ BMI & 0.026 & 0.441 & .329 & Not significant & Rejected \\
Body Image $\rightarrow$ Eating habit $\rightarrow$ BMI & -0.009 & -0.150 & .441 & Not significant & Rejected \\
Self-esteem $\rightarrow$ BMI $\rightarrow$ Cognitive reactivity & 0.055 & 0.663 & .255 & Not significant & Rejected \\
Body attitude $\rightarrow$ BMI $\rightarrow$ Cognitive reactivity & 0.005 & 0.083 & .466 & Not significant & Rejected \\
Eating habit $\rightarrow$ BMI $\rightarrow$ Cognitive reactivity & & & & &
\end{tabular}

Source: Primary data, 2020

Table 8

One-way ANOVA Results

\begin{tabular}{|c|c|c|c|c|c|c|c|c|}
\hline \multirow{3}{*}{$\begin{array}{l}\text { Variable } \\
\text { Self-esteem }\end{array}$} & \multirow{3}{*}{$\begin{array}{l}\text { BMI } \\
\text { Normal }\end{array}$} & \multirow{3}{*}{$\begin{array}{l}\mathrm{N} \\
100\end{array}$} & \multirow{3}{*}{$\begin{array}{l}\text { Mean } \\
28.50\end{array}$} & \multirow{3}{*}{$\begin{array}{l}\text { F } \\
5.051\end{array}$} & \multirow{3}{*}{$\begin{array}{l}\mathrm{p} \\
.008\end{array}$} & \multicolumn{3}{|c|}{ Bonferroni Test } \\
\hline & & & & & & \multicolumn{3}{|c|}{ Mean Difference (J) } \\
\hline & & & & & & Normal & Overweight & -0.29 \\
\hline & Overweight & 14 & 28.79 & & & Normal & Obese & $3.04 *$ \\
\hline & Obese & 26 & 25.46 & & & Overweight & Obese & 3.32 \\
\hline \multirow[t]{3}{*}{ Body attitude } & Normal & 100 & 88.07 & 5.614 & .005 & Normal & Overweight & 2.28 \\
\hline & Overweight & 14 & 85.79 & & & Normal & Obese & $6.53^{*}$ \\
\hline & Obese & 26 & 81.54 & & & Overweight & Obese & 4.25 \\
\hline \multirow[t]{3}{*}{ Eating habit } & Normal & 100 & 93.72 & 0.481 & .619 & Normal & Overweight & 2.29 \\
\hline & Overweight & 14 & 91.43 & & & Normal & Obese & -0.13 \\
\hline & Obese & 26 & 93.85 & & & Overweight & Obese & -2.42 \\
\hline \multirow{3}{*}{$\begin{array}{l}\text { Cognitive } \\
\text { reactivity }\end{array}$} & Normal & 100 & 69.28 & 1.688 & .189 & Normal & Overweight & 0.93 \\
\hline & Overweight & 14 & 68.36 & & & Normal & Obese & -5.41 \\
\hline & Obese & 26 & 74.69 & & & Overweight & Obese & -6.33 \\
\hline
\end{tabular}

$* \mathrm{p}<.05$

Source: Primary data, 2020

Descriptive and comparative results

A total of 140 female college students aged 1822 years old $(M=19.93 \pm 1.29)$ are involved in this research. Most participants were categorized as BMI normal $(71.42 \%, \mathrm{~N}=100)$, while $10 \%(\mathrm{~N}=14)$ were categorized as overweight and $18.57 \%$ were categorized as obese $(\mathrm{N}=26)$. Through closed questions, participants were also asked about several things. It is figured that only $7.5 \%$ of participants considered their weight is already ideal, among 25\% who has a romantic relationship, $10 \%$ of them felt criticized by their partner about their physical appearances. Furthermore, most $75 \%$ of participants paid attention to the physical appearance of friends, model figures, and celebrities, $65 \%$ of the total subjects were given nicknames based on their physical appearance, which makes them feel discomfort.

Results from the one-way ANOVA test show that there was a significant difference in selfesteem in the BMI group ( $\mathrm{F}=5.051 ; \mathrm{p}=.008)$ where obese subjects had lower self-esteem (M = 25.46) compared to normal subjects ( $M=28.50)$ and overweight $(\mathrm{M}=28.79)$. Furthermore, there was a significant difference in body attitude in the BMI group ( $F=5.614 ; \mathrm{p}=.005)$ where subjects with obesity had lower body attitude $(\mathrm{M}=81.54)$ compared to normal subjects $(\mathrm{M}=88.07)$ and overweight $(\mathrm{M}=85.79)$. Then, there was no significant difference in eating habits $(F=0.481$; $p$ 
$=.619)$ and cognitive reactivity $(\mathrm{F}=1.688 ; \mathrm{p}=$ .189) in the BMI group.

Further, post hoc comparisons using the Bonferroni correction indicated that the selfesteem of group with normal BMI (M=28.50) was significantly different from the obese group ( $\mathrm{M}=$ 25.46). The body attitude of normal group ( $M=$ 88.07) was significantly different from the obese group $(\mathrm{M}=81.54)$.

\section{Discussion}

This research shows that self-esteem significantly affects body attitude. In several studies, female college students who have positive selfesteem will be able to assess and evaluate themselves positively and can accept their physical condition and appearance (Gatti et al, 2014; Wasylkiw et al., 2012). Satisfaction with body image significantly influences self-esteem in young women (Pisitsungkagarn et al., 2014). Interestingly, in this study, self-esteem does not significantly affect eating habits. We assumed food as a coping mechanism to endure the problem that they encounter during their college life. Adolescents who use this coping strategy were reported to develop less healthy eating habits (MartynNemeth et al., 2009). Chung, Kim, and Woo (2007) in their research stated that eating habits will be influenced by stressful situations related to their class activities. Besides, the rhythm of campus life where classes are held in the morning, and many tasks are situational that affect their eating habits.

It was revealed in the result of this research that self-esteem influence one indicator of weight state, which is BMI. This finding agrees with the previous studies which proved that self-esteem was significantly associated with weight status (Alvani et al., 2016). According to Strasburger (2010) evaluation of the body is influenced by some factors, one of them is BMI. BMI correlates with the satisfaction or dissatisfaction of an individual toward an individuals' body. For women, their physical appearance, especially body weight, is the most crucial point that can influence self-esteem (Gentile et al., 2009). Obesity or overweight is one of the most determining factors of self-esteem and body image among women (Unlu et al, 2019). This is supported by the findings in this study that participants with obesity have low self-esteem. A college student with medium and high self-esteem has the highest probability to be in a healthy weight condition, and less likely to be overweight (Alvani et al., 2016). According to other studies, the association between self-esteem and BMI among females was the strongest when they are between ages 22 to 32 (Kiviruusu et al., 2016).

This research found that self-esteem influences cognitive reactivity in female college students. In line with it, Teixeira, Pereira, Marques, Saraiva, and Macedo (2016) state that an individual's self-esteem strongly affects their reactivity level. Low level of self-esteem in women is related to cognitive factors such as perfectionism, and this factor promotes the development of eating disorders like binge eating because they doubt their ability to lose weight. Ostovar, Md Nor, Griffiths, and Chermahini (2017) said that cognitive reactivity can be seen from 5 things namely: hopelessness (suicidality), acceptance (coping), aggression, control (perfectionism), risk aversion, and rumination. Various studies support the results of this study which show self-esteem is significantly negatively correlated with aspects of cognitive reactivity. A study conducted by Cakar (ERIC - EJ1050481 - The Effect of Automatic Thoughts on Hopelessness: Role of Self-Esteem as a Mediator, Educational Sciences: Theory and Practice, 2014, n.d.) on 338 students shows that 
low self-esteem can affect the emergence of automatic thoughts in the form of hopelessness. Besides, low self-esteem correlates with low selfacceptance (Macinnes, 2006), high-risk aversion (Johanson, 2000), habitual rumination (Phillips \& Hine, 2016), maladaptive perfectionism (Rice \& Lopez, 2004), and high aggressiveness in college students (Trzesniewski et al., 2006). Clasen, Fisher, and Beevers (2015) add that someone who has low self-esteem will show a pattern of cognitive reactions that tend to have high levels of sadness and are simultaneously more susceptible to depression. It is also worth mentioning that Clasen, et al (2015) and Rosenberg -in Nelis \& Bukowski (2019)- explain that self-esteem also has a reactive response towards emerging distress in daily life.

Attitude toward the body has proved to significantly affect individuals' eating habits. Further, it also affects body weight. The obese female participants showed a lower body attitude compared to the other two groups. A crosssectional study of students conducted by Aoun, et al (2019) revealed the cognitive, behavioral, and emotional aspects of eating habits by analyzing body mass index, circadian rhythm, eating behavior, and anxiety in individuals. The results of this study indicate the influence of gender on eating behavior. Women reportedly exhibit emotionally higher eating behavior than men. Impulsivity in eating behavior is related to individuals' perceptions about their body which ultimately affects cognitive restraint, which is the intention to control food intake. Obesity is associated with the behavior and cognitive conditions of individuals (Jansen et al., 2015).

Based on this study, eating habit and attitude among female college students was also related to their cognitive reactivity. This finding is consistent with a study among university students in Lebanon which showed significant correlations between three cognitive and emotional domains related to eating habits (Aoun et al., 2019). Females turn out to be more emotional eaters than males, they tend to overcome their negative feelings by eating, while men choose other ways of coping such as gambling or alcohol drinking (Aoun et al., 2019). Women in this research showed that their eating habits and diet $d$ were related to their acceptance of certain parts of the body. This finding agrees with another study which also highlighted a link between dieting and negative thinking, which fosters unhealthy eating patterns among adults (Wehling \& Lusher, 2019).

Furthermore, it was found that an individual's way of thinking is more affected by their perception of their weight rather than the actual weight. Individuals who perceive their bodies as too fat, even though the BMI (Body Mass Index) calculation shows a normal reading, will tend to assume that food is something that needs to be avoided. Also, Clasen et al., (2015) add that individual way of thinking is influenced by their self-esteem. So, even though individuals with high body weight will tend to have positive ways of thinking if they have positive self-esteem. Bodyweight in this study also proved to not affect a mediating relation of all variables.

Research conducted by Alvani, et al (2016) on 450 students showed a strong relationship between a person's self-esteem and body weight. Overweight individuals are reported to have lower self-esteem compared to normal-weight individuals. Further, they recommend the clinical practice to add self-esteem improvement programs in their weight management. Besides self-esteem, gender also influences body weight. Unhealthy dietary behavior is often associated with low self-esteem 
(Mostafavi et al., 2013). This research also revealed that the correlation between self-esteem and eating habit is mediated by body image among female college students. This finding is related to the result of a study held by Kim and Lennon which found that low self-esteem, body dissatisfaction, and overall appearance dissatisfaction were associated with the risk of eating disorder tendencies (Kim \& Lennon, 2007). Women who are dissatisfied with their bodies usually have lower self-esteem and showed more eating disorder symptoms (Kim \& Lennon, 2007). Santamaría, Vázquez, Caballero, and Rodríguez (2009) state that the same eating habit may have a different effect on an individual with normal weight or excessive weight. Women with normal weight are reported to control their food more easily than women with excessive weight. Attitude toward the body generally correlates with the pattern or eating habits of an individual. Hidayah and Bariah (2011) show that attitude toward the body reflects an individual's effort to control food and it affects the eating habit. Dissatisfaction about the shape of the body may push an individual to have restricted diets, over workout, and refusing to digest food by vomiting or consuming laxative pills. This finding is also consistent with a study by Kesgin which found that there were some studies about the relationship between self-esteem and eating disorders among adolescents in clinical practices, and the main issue underlying this connection is women's self-criticism regarding their physical appearance (Kesgin, 2019).

Uçar et al., (2010) suggest that there is a positive relationship between self-esteem and attitude towards the body, individual satisfaction with the body influences positive self-acceptance and evaluation. Individuals who have a positive attitude towards the body can accept their strengths and weaknesses without feeling inferior (Hasmalawati, 2017). High levels of self-esteem have been shown to increase individual adjustment and health-related behaviors (Yun et al., 2019). Attitudes toward the body moderate the effect of self-esteem on individual body weight. Research conducted by O'Dea (2006) recommends that in obesity prevention programs, efforts are needed to build clients' self-esteem first. By developing healthy eating habits and regular physical activity without fear of food, this will encourage the creation of positive attitudes towards the body that are beneficial in the process of regulating body weight. Positive evaluation of the body provides an opportunity to achieve a healthier physical and mental state.

\section{Conclusion}

The findings showed that positive self-esteem is an essential variable in determining the way individuals view their bodies and then reactivity to think about a situation. Furthermore, the attitude towards the body would affect individual eating habits and body weight. Positive eating habits contribute to resolving eating habit issues. Students with a positive attitude towards the body indirectly affect the strong relationship between self-esteem and eating habits. Based on the results described above, the implications that can be drawn out from this research are the need for developing psychological intervention programs related to the topic of self-esteem and its relation to the health-education promotion program to enhance lifestyle decisions.

The generalizability of the findings of this study is limited because we only took the samples from female students of only one university; the size of the sample may not be very representative. For future studies, samples from different 
universities may provide a more inclusive picture. Future researchers may also need to take into consideration participants' socio-economic status, food behavior, and lifestyle factors. Also, comparison with male university students combined with cross-cultural studies will provide more comprehensive results and benefits.

\section{Acknowledgment}

The researcher would like to acknowledge all the participants of the research. Our deepest gratitude goes to our research assistants: Ayu Kurnia, Nanda Erfani, Valentino Marcel Tahamata, and Tsara Firdaus.]

\section{References}

Abdel-Khalek, A. M. (2016). Introduction to the psychology of self-esteem. In F. Holloway (Ed.), Self Esteem, perspectives, influences and improvement strategies (pp. 1-23). Nova Science Publishers, Inc.

Alasmari, H. D., Al-Shehri, A. D., Aljuaid, T. A., Alzaidi, B. A., \& Alswat, K. . (2017). Relationship between body mass index and obesity awareness in school students. Journal of Clinical Medicine Research, 9(6), 520-524. https://doi.org/10.14740/jocmr2987w.

Alvani, S. R., Mehrshad, S., Hosseini, P., \& Kimura, L. W. (2016). Relationship between Body Weight and Self-Esteem: A Study of Young Men and Women in Iran. Journal of Obesity and Overweight, 2(2). https://doi.org/10.15744/2455-7633.2.202

Aoun, C., Nassar, L., Soumi, S., El Osta, N., Papazian, T., \& Rabbaa Khabbaz, L. (2019). The cognitive, behavioral, and emotional aspects of eating habits and association with impulsivity, chronotype, anxiety, and depression: A cross-sectional study. Frontiers in Behavioral Neuroscience, 13. https://doi.org/10.3389/fnbeh.2019.00204

Balitbangkes. (2018). Riset Kesehatan Dasar. Kementrian Kesehatan Republik Indonesia.

Beaton, D. E., Bombardier, C., Guillemin, F., \& Ferraz, M. B. (2000). Guidelines for the process of Cross Cultural adaptation of Self Report mesures. Spine, 25(24), 3186-3191. https://doi.org/10.1097/00007632-200012150-00014

Blair, A. (2016). Understanding first-year students' transition to university: A pilot study with implications for student engagement, assessment, and feedback. Politics, 37(2), 215-228. https://doi.org/10.1177/0263395716633904

Chin, W. W. (1998). The partial least squares approach for structural equation modeling. In Modern methods for business research (pp. 295-336). Lawrence Erlbaum Associates Publishers.

Chung, H.-K., Kim, M.-H., \& Woo, N. (2007). The effect of life stress on eating habit of university students in Chungcheongnam-do Province. Journal of the Korean Society of Food Culture, 22(2), 176-184.

Clasen, P. C., Fisher, A. J., \& Beevers, C. G. (2015). Mood-reactive self-esteem and depression vulnerability: person-specific symptom dynamics via smart phone assessment. PLoS One, 10(7), e0129774. https://doi.org/10.1371/journal.pone.0129774

Da Rocha Morgado, F. F., Campana, A. N. N. B., Da Consolação, M., \& Tavares, G. C. F. (2014). Development and validation of the self-acceptance scale for persons with early blindness: The SAS-EB. PLoS ONE, 9(9). https://doi.org/10.1371/journal.pone.0106848 
Davis, E. M., Zyzanski, S. J., Olson, C. M., Stange, K. C., \& Horwitz, R. I. (2009). Racial, ethnic, and socioeconomic differences in the incidence of obesity related to childbirth. American Journal Public Health, 99(2), 249-299. https://doi.org/10.2105/AJPH.2007.132373.

Debeuf, T., Verbeken, S., Van Beveren, M.-L., Michels, N., \& Braet, C. (2018). Stress and eating behavior: A daily diary study in youngsters. Frontiers in Psychology, 9. https://doi.org/10.3389/fpsyg.2018.02657

Deshpande, S., Basil, M. D., \& Basil, D. Z. (2009). Factors influencing healthy eating habits among college students: An application of the health belief model. Health Marketing Quarterly, 26(2), 145-164. https://doi.org/10.1080/07359680802619834

ERIC - EJ1050481 - The Effect of Automatic Thoughts on Hopelessness: Role of Self-Esteem as a Mediator, Educational Sciences: Theory and Practice, 2014. (n.d.). Retrieved July 31, 2020, from https://eric.ed.gov/?id=EJ1050481

Gatti, E., Ionio, C., Traficante, D., \& Confalonieri, E. (2014). “I like my body; therefore, I like myself”: How body image influences self-esteem-A cross-sectional study on Italian adolescents. Europe's Journal of Psychology, 10(2), 301-317. https://doi.org/10.5964/ejop.v10i2.703

Gentile, B., Grabe, S., Dolan-Pascoe, B., Twenge, J. M., Wells, B. E., \& Maitino, A. (2009). Gender differences in domain-specific self-esteem: A meta-analysis. Review of General Psychology, 13(1), 34-45. https://doi.org/10.1037/a0013689

Gerend, M. A. (2009). Does calorie information promote lower calorie fast food choices among college students? Journal Adolescent Health, 44(1), 84-86.

Hair, J. F., Ringle, C. M., \& Sarstedt, M. (2011). PLS-SEM: Indeed a silver bullet. Journal of Marketing Theory and Practice, 19(2), 139-152. https://doi.org/10.2753/MTP1069-6679190202

Harriger, J. A., \& Thompson, J. K. (2012). Psychological consequences of obesity: Weight bias and body image in overweight and obese youth. International Review of Psychiatry, 24(3), 247-253. https://doi.org/10.3109/09540261.2012.678817

Hasmalawati, N. (2017). Pengaruh citra tubuh dan perilaku makan terhadap penerimaan diri pada $\begin{array}{llll}\text { wanita. } & \text { Psikoislamedia: Jurnal Psikologi, 2(2), 107-115. }\end{array}$ https://doi.org/10.22373/psikoislamedia.v2i2.1892

Hebden, L., Chan, H. N., Louie, J. C., Rangan, A., \& Allman-Farinelli, M. (2015). You are what you choose to eat: factors influencing young adults' food selection behaviour. Journal of Human Nutrition and Dietetics, 28(4), 401-408. https://doi.org/10.1111/jhn.12312

Heider, N., Spruyt, A., \& De Houwer, J. (2015). Implicit beliefs about ideal body image predict body image dissatisfaction. Frontiers in Psychology, 6(OCT). https://doi.org/10.3389/fpsyg.2015.01402

Hidayah, G. N., \& Syahrul Bariah, A. H. (2011). Eating attitude, body image, body composition and dieting behaviour among dancers. Asian Journal of Clinical Nutrition, 3(3), 92-102. https://doi.org/10.3923/ajcn.2011.92.102

Hunot, C., Fildes, A., Croker, H., Llewellyn, C. H., Wardle, J., \& Beeken, R. J. (2016). Appetitive traits and relationships with BMI in adults: Development of the Adult Eating Behaviour Questionnaire. Appetite, 105, 356-363. https://doi.org/10.1016/j.appet.2016.05.024

Hye Kyung, K., \& Jin Hee, K. (2009). Relationship between stress and eating habits of adults in Ulsan. Korean Journal Nutrion, 42(6), 536-546.

Jansen, A., Houben, K, \& Roefs, A. (2015). A cognitive profile of obesity and its translation into new interventions. Frontiers in Psychology, 6, 1807. https://doi.org/10.3389/fpsyg.2015.01807 
Johanson, J. C. (2000). Correlations of self-esteem and intolerance of ambiguity with risk aversion. Psychological Reports, 87(2), 534-534. https://doi.org/10.2466/pr0.2000.87.2.534

Kakoschke, N., Aarts, E., \& Verdejo-García, A. (2019). Erratum: The cognitive drivers of compulsive eating behavior (Frontiers in Behavioral Neuroscience, (2019), 12, 10.3389/fnbeh.2018.00338). Frontiers in Behavioral Neuroscience, 13(October), 3389. https://doi.org/10.3389/fnbeh.2019.00230

Kesgin, C. E. (2019). The Relationship between Eating Attitudes and Self-Esteem among University Students. Journal Homepage: International Journal of Research in Social Sciences, 9(4), 22492496.

Kim, J. H., \& Lennon, S. J. (2007). Mass media and self-esteem, body image, and eating disorder tendencies. Clothing and Textiles Research Journal, 25(1), 2-23. https://doi.org/10.1177/0887302X06296873

Kiviruusu, O., Konttinen, H., Huurre, T., Aro, H., Marttunen, M., \& Haukkala, A. (2016). Self-esteem and Body Mass Index from adolescence to mid-adulthood. A 26-year follow-up. International Journal of Behavioral Medicine, 23(3), 355-363. https://doi.org/10.1007/s12529-015-9529-4

Kurniawan, M. Y., Briawan, D., \& Caraka, R. E. (2015). Persepsi tubuh dan gangguan makan pada remaja. Jurnal Gizi Klinik Indonesia, 11(3), 105. https://doi.org/10.22146/ijcn.19287

Macinnes, D. L. (2006). Self-esteem and self-acceptance: An examination into their relationship and their effect on psychological health. Journal of Psychiatric and Mental Health Nursing, 13(5), 483-489. https://doi.org/10.1111/j.1365-2850.2006.00959.x

Martyn-Nemeth, P., Penckofer, S., Gulanick, M., Velsor-Friedrich, B., \& Bryant, F. B. (2009). The relationships among self-esteem, stress, coping, eating behavior, and depressive mood in adolescents. Research in Nursing \& Health, 32(1), 96-109. https://doi.org/10.1002/nur.20304

Minkwitz, J., Scheipl, F., Cartwright, L., Campbell, I. C., Chittka, T., Thormann, J., Hegerl, U., Sander, C., \& Himmerich, H. (2019). Why some obese people become depressed whilst others do not: exploring links between cognitive reactivity, depression and obesity. Psychology, Health and Medicine, 24(3), 362-373. https://doi.org/10.1080/13548506.2018.1524153

Montgomery Sklar, E. (2017). Body Image, Weight, and Self-Concept in Men. American Journal of Lifestyle Medicine, 11(3), 252-258. https://doi.org/10.1177/1559827615594351

Mostafavi, F., Azadbakht, L., \& Daniali, S. (2013). Relationship between body satisfaction with self esteemand unhealthy body weight management. Journal of Education and Health Promotion, 2(1), 29. https://doi.org/10.4103/2277-9531.115804

Nelis, S., \& Bukowski, W. M. (2019). Daily affect and self-esteem in early adolescence: Correlates of mean levels and within-person variability. Psychologica Belgica, 59(1), 96-115. https://doi.org/10.5334/pb.467

O'Dea, J. A. (2006). Self-concept, self-esteem and body weight in adolescent females. Journal of Health Psychology, 11(4), 599-611. https://doi.org/10.1177/1359105306065020

Ostovar, S., Md Nor, M. B., Griffiths, M. D., \& Chermahini, S. A. (2017). Cognitive reactivity: Cultural adaptation and psychometric testing of the Persian version of the Leiden Index of Depression Sensitivity Revised (LEIDS-R) in an Iranian sample. International Journal of Mental Health and Addiction, 15(3), 621-638. https://doi.org/10.1007/s11469-016-9713-z

Peltzer, K., Pengpid, S., Alafia Samuels, T., Özcan, N. K., Mantilla, C., Rahamefy, O. H., Wong, M. L., \& Gasparishvili, A. (2014). Prevalence of overweight/obesity and its associated factors among 
university students from 22 countries. International Journal of Environmental Research and Public Health, 11(7), 7425-7441. https://doi.org/10.3390/ijerph110707425

Perrin, E. M., Boone-Heinonen, J., Field, A. E., Coyne-Beasley, T., \& Gordon-Larsen, P. (2009). Perception of overweight and self-esteem during adolescence. International Journal of Eating Disorders, 43(2), 447-454. https://doi.org/10.1002/eat.20710

Phillips, W. J., \& Hine, D. W. (2016). En route to depression: Self-esteem discrepancies and habitual Rumination. Journal of Personality, 84(1), 79-90. https://doi.org/10.1111/jopy.12141

Pisitsungkagarn, K., Taephant, N., \& Attasaranya, P. (2014). Body image satisfaction and self-esteem in Thai female adolescents: the moderating role of self-compassion. International Journal of Adolescent Medicine and Health, 26(3), 333-338. https://doi.org/10.1515/ijamh-2013-0307

Pöhlmann, K., Roth, M., Brähler, E., \& Joraschky, P. (2013). The Dresden Body Image Inventory (DKB35): Validity in a clinical sample. PPmP - Psychotherapie $\cdot$ Psychosomatik $\cdot$ Medizinische Psychologie, 64(03/04), 93-100. https://doi.org/10.1055/s-0033-1351276

Purnell, J. . (2018). Definitions, Classification, and Epidemiology of Obesity ( et al. Feingold KR, Anawalt B, Boyce A (Ed.)). MDText.com, Inc.

Racette, S. B., Deusinger, S. S., Strube, M. J., Highstein, G. R., \& Deusinger, R. . (2008). Changes in weight and health behaviors from freshman through senior year of college. Journal of Nutrition Educatioan Behavior, 40, 39-42.

Ramalho, A. A., Dalamaria, T., \& de Souza, O. F. (2012). Consumo regular de frutas e hortaliças por estudantes universitários em Rio Branco, Acre, Brasil: Prevalência e fatores associados. Cadernos de Saude Publica, 28(7), 1405-1413. https://doi.org/10.1590/S0102311X2012000700018

Rice, K. G., \& Lopez, F. G. (2004). Maladaptive perfectionism, adult attachment, and self-esteem in college students. Journal of College Counseling, 7(2), 118-128. https://doi.org/10.1002/j.21611882.2004.tb00243.x

Santamaría, A. R., Vázquez, I. A., Caballero, M. D. P., \& Rodríguez, C. F. (2009). Eating habits and attitudes and their relationship with Body Mass Index (BMI). The European Journal of Psychiatry, 23(4), 214-224. https://doi.org/10.4321/s0213-61632009000400002

Scher, C. D., Ingram, R. E., \& Segal, Z. V. (2005). Cognitive reactivity and vulnerability: Empirical evaluation of construct activation and cognitive diatheses in unipolar depression. Clinical Psychology Review, 25(4), 487-510.

Sogari, G., Velez-Argumedo, C., Gómez, M. I., \& Mora, C. (2018). College students and eating habits: A study using an ecological model for healthy behavior. Nutrients, 10(12). https://doi.org/10.3390/nu10121823

Stets, J. E., \& Burke, P. J. (2014). Self-esteem and identities. Sociological Perspectives, 57(4), 409-433. https://doi.org/10.1177/0731121414536141

Strasburger, V. (2010). Children, adolescents, and the media. Pediatric Annals, 39(9), 538-540. https://doi.org/10.3928/00904481-20100825-02

Tapera, R., Marapelo, B. T., Tumoyagae, T., Maswabi, T. M., Erick, P., Letsholo, B., \& Mbongwe, B. (2017). The prevalence and factors associated with overweight and obesity among University of Botswwana students. Journal Gogent Medicine, 4(1). 
Teixeira, M. D., Pereira, A. T., Marques, M. V., Saraiva, J. M., \& Macedo, A. F. de. (2016). Eating behaviors, body image, perfectionism, and self-esteem in a sample of Portuguese girls. Revista Brasileira de Psiquiatria, 38(2), 135-140. https://doi.org/10.1590/1516-4446-2015-1723

Trzesniewski, K. H., Donnellan, M. B., Moffitt, T. E., Robins, R. W., Poulton, R., \& Caspi, A. (2006). Low selfesteem during adolescence predicts poor health, criminal behavior, and limited economic prospects during adulthood. Developmental Psychology. https://doi.org/10.1037/00121649.42.2.381

Uçar, A., Aynur, B., Ayhan, F., Pınar, Ç., \& Neriman, A. (2010). A study on the relationship between body image acceptance and self-esteem among adolescents of normal and abnormal body weight. The International Journal of Learning: Annual Review, 17(8), 251-260. https://doi.org/10.18848/1447-9494/CGP/v17i08/47173

Unlu, S., Aykut, M., Borlu, A., \& Kaner, G. (2019). Are low self-esteem and body image dissatisfaction related with body mass index? Progress in Nutrition, 21(5), 94-103. https://doi.org/10.23751/pn.v21i1-S.5552

Van der Does, W. (2002). Cognitive reactivity to sad mood: Structure and validity of a new measure. Behaviour Research and Therapy, 40(1), 105-119. https://doi.org/10.1016/S00057967(00)00111-X

Vella-Zarb, R. A., \& Elgar, F. J. (2009). The 'freshman 5': A meta-analysis of weight gain in the freshman year of college. Journal American College Health, 58, 161-166.

Wasylkiw, L., MacKinnon, A. L., \& MacLellan, A. M. (2012). Exploring the link between self-compassion and body image in university women. Body Image, 9(2), 236-245. https://doi.org/10.1016/j.bodyim.2012.01.007

Wehling, H., \& Lusher, J. M. (2019). Cognitive and Emotional Influences on Eating Behaviour : A Qualitative Perspective. https://doi.org/10.1177/1178638819855936

Yun, E. K., Lee, H., Lee, J. U., Park, J. H., Noh, Y. M., Song, Y. G., \& Park, J. H. (2019). Longitudinal effects of Body Mass Index and self-esteem on adjustment from early to late adolescence. Journal of Nursing Research, 27(1), e2. https://doi.org/10.1097/jnr.0000000000000266 
This page intentionally left blank. 